\title{
A COMPARATIVE AND CORELATIVE STUDY ON BODY COMPOSITION AND MOTOR PERFORMANCE OF 14 YEARS OLD BOYS OF FOUR DIFFERENT ALTITUDES OF DARJEELING DISTRICT
}

\author{
Jyan Chandra Gurung ${ }^{1}$--- Krishna Banerjee ${ }^{2}$ \\ 'Assistant Teacher, Kadamtala High School, Near B.S.F Headquater, Darjeeling, State: West Bengal, India \\ ${ }^{2}$ Professor, Department of physical education, Kalyani University, State: West Bengal, India
}

\begin{abstract}
The purpose of the study was to find out the difference in Body composition (skinfolds) and motor performance of 14 years old boys of Darjeeling. The samples are school students. Researcher had taken 100 male students each from Sukhia Pokhari Higher Secondary School (Alt.-7200 ft.), Trunbull higher Secondary school (Alt.-6700 ft.), Jnanpith High school (Alt.-3000 ft.) and Kadamtala High School(Alt.$430 \mathrm{ft}$.). Researcher had measured height and weight as personal data measured skinfolds of triceps, biceps, subscapular, supra spinale, iliac creast and medial calf for body composition. $50 \mathrm{mt}$. dash, shuttle run, standing broad jump and sit ups were motor performance parameters. It has been observed that there were significant differences in medial calf skinfold thickness, agility and strength endurance.
\end{abstract}

Keywords: Body composition, Motor performance, Male students.

Received: 5 August 2014/ Revised: 27 August 2014/ Accepted: 3 September 2014/ Published: 6 September 2014

\section{Contribution/ Originality}

This study contributes in the existing literature as very few anthropometrical researches had conducted in the hilly area of Darjeeling. This study uses new estimation methodology and tried to provide the unbiased and exact findings. It is a thrust area of research as there are differences in anthropometric and motor variation due to altitude difference. The paper's primary contribution is finding that how difference in anthropometric and motor difference occurs with increases or decreases in altitude and to set the physical education programme according to the need of the students living at different altitudes.

\section{INTRODUCTION}

The body fat percentage is a measure of fitness level, since it is the only body measurement which directly calculates a person's relative body composition without regard to height or weight. The widely used body mass index (BMI) provides a measure that allows the comparison of the 
adiposity of individuals of different heights and weights. While BMI largely increases as adiposity increases, due to differences in body composition, it is not an accurate indicator of body fat; for example, individuals with greater muscle mass will have higher BMIs. The thresholds between "normal" and "overweight" and between "overweight" and "obese" are sometimes disputed for this reason.

In current contexts, Physical fitness is considered a measure of the body's ability to function efficiently and effectively in work and leisure activities, to be healthy, to resist hypokinetic diseases, and to meet emergency situations. American association of health physical education Recreation and dance adopted a new approach, physical fitness has now been dichotomized into two areas, and they are: Health related fitness and Motor fitness.

Body compositions including skin fold thickness are the determinant factor for physical performance especially in the activities where the total body has to be moved. In addition substantial amount of evidence are available to notify that length, breadth and girth of the body bone has an immense impact on physical performance and similarly high percentage of body fat not only serves as dead weight but it also reveals that the relative ability to supply oxygen to the working muscles thus cutting down on cardio-vascular endurance.

Motor Fitness refers to the ability of an athlete to perform successfully at their sport. It refers to the capability of an athlete to perform effectively at their particular sport. The components of motor fitness are: agility, balance, co-ordination, power which entails speed and strength and finally reaction time.

Here as narrated in the title 'altitude' means height. As we go up the hills we have to accompanied with various changes such as decrease in total barometric pressure, decrease in partial pressure in oxygen, decrease in density of air, cooler and dryer air, climatic change like low temperature, nature of daily activity, haemoglobin quantity etc. From various studies it has become clear that altitude has a great effect on physical as well as anthropometric status of the population.

As the body composition and motor fitness is discussed above now let us understand why we can expect the variation in above mention factors in different altitude. Firstly in this paper body composition means skin fold thickness i.e, fat present beneath the skin. Generally it is known that with increase in altitude temperatures decreases and in this study there are four different altitudes i.e, $430 \mathrm{ft}$., $3000 \mathrm{ft}$., $6700 \mathrm{ft}$. and $7200 \mathrm{ft}$. As we know that fat is used as insulator by human body we can aspect the thicker layer of fat with increase in altitude. Apart from this, genetic factor may also play a vital role in thicker skinfolds thickness in higher altitude. It will be very interesting if we get clues regarding anthropometric variation including pattern of growth, fat deposition etc. in respect of altitude from the study.

In case of motor performance we can expect better performance of higher altitude students in case of 50 meter dash, agility and shuttle run because in hill areas i.e, in high altitudes people have to walk ups and down the narrow roads for their daily livelihood including their daily school. So for their daily works they need more strength than plain i.e, low altitude counterparts. Apart from these the haemoglobin level is high in high altitudes as haemoglobin carries oxygen so increase in 
haemoglobin means increase in performance. But in case of sit ups it can be predicted that lower altitude students may have more strength endurance as because they have comparatively shorter upper part than high altitude counterparts.

\section{METHODS}

\subsection{Purpose of the Study}

The purpose of the study was to find out the difference in body composition and motor performance of 14 years old school going male adolescents.

\subsection{The Subjects}

One hundred twelve schools going male students from four different altitudes were selected randomly as the subject of study. The altitudes were 430 feet, 3000 feet, 6700 feet and 7200 feet respectively. The age of the subjects was 14 years.

\subsection{Criterion Measures}

Researcher had measured age, height and weight as personal data and measured the following parameters;

Table-1. Criterion measures

\begin{tabular}{|c|c|c|}
\hline Personal Data & Skin-Folds & Motor Fitness Variables \\
\hline $\begin{array}{ll}\text { 1. } & \text { Age } \\
\text { 2. } & \text { Height } \\
\text { 3. } & \text { weight }\end{array}$ & $\begin{array}{l}\text { 1.Triceps, } 2 . \text { Biceps, } \\
\text { 3.Subscapular, 4.Supra spinale, } \\
\text { 5.Iliac creast, 6.Medial calf }\end{array}$ & $\begin{array}{l}\text { 1. } 50 \text { mt. dash } \\
\text { 2. Standing broad jump } \\
\text { 3. Sit ups 4.Shuttle run }\end{array}$ \\
\hline
\end{tabular}

\section{RESULT AND DISCUSSION}

Table-2. Mean and S.D of height and weight of four different altitudes

\begin{tabular}{l|l|l|l|l|l}
\hline Age 13 & \multicolumn{3}{|l|}{ Height } & \multicolumn{2}{l}{ Weight } \\
\hline & N & Mean & SD & Mean & SD \\
\hline Sukhiapokhori HS School & 25 & 1.52 & 0.077 & 41.12 & 6.790 \\
\hline Trunbull HS School & 25 & 1.56 & 0.074 & 43.04 & 7.684 \\
\hline Jnanpith High School & 25 & 1.57 & 0.054 & 42.88 & 4.790 \\
\hline Kadamtala High School & 25 & 1.58 & 0.065 & 44.20 & 7.118 \\
\hline
\end{tabular}

From the above table it was found that the mean height of Group-I (7200 ft.), Group-II (6700 ft.), Group-III (3000 ft.) and Group-IV (430 ft.) were $1.52 \mathrm{mt}$., $1.56 \mathrm{mt}, 1.57 \mathrm{mt}$. and $1.58 \mathrm{mt}$. Similarly the mean weights were $41.12 \mathrm{~kg} ., 43.04 \mathrm{~kg} ., 42.88 \mathrm{~kg}$. and $44.20 \mathrm{~kg}$. 
Table-3. Mean and S.D of skinfold measurements of four different altitudes

\begin{tabular}{|c|c|c|c|c|c|c|c|c|c|}
\hline & & \multicolumn{4}{|l|}{ Biceps } & \multicolumn{4}{|c|}{ Triceps } \\
\hline Altitude & $\mathbf{N}$ & Mean & SD & $\begin{array}{l}\text { SEm } \\
( \pm)\end{array}$ & $\begin{array}{l}\text { CD } \\
(P=0.05)\end{array}$ & Mean & SD & $\begin{array}{l}\text { SEm } \\
( \pm)\end{array}$ & $\begin{array}{l}\text { CD } \\
(P=0.05)\end{array}$ \\
\hline \multicolumn{10}{|l|}{ Age 13} \\
\hline Sukhiapokhori HS School & 25 & 2.04 & 0.476 & 0.110 & NS & 4.27 & 1.422 & 0.247 & NS \\
\hline Trunbull HS School & 25 & 2.24 & 0.688 & 0.110 & $\mathrm{NS}$ & 4.46 & 1.466 & 0.247 & NS \\
\hline Jnanpith High School & 25 & 2.03 & 0.346 & 0.110 & $\mathrm{NS}$ & 3.92 & 0.686 & 0.247 & NS \\
\hline \multirow[t]{2}{*}{ Kadamtala High School } & 25 & 2.03 & 0.619 & 0.110 & $\mathrm{NS}$ & 3.57 & 1.203 & 0.247 & NS \\
\hline & & \multicolumn{4}{|c|}{ Sub Scapular } & \multicolumn{4}{|c|}{ Supra Spinale } \\
\hline \multicolumn{10}{|l|}{ Age 13} \\
\hline Sukhiapokhori HS School & 25 & 3.67 & 1.121 & 0.181 & NS & 3.16 & 1.277 & 0.266 & NS \\
\hline Trunbull HS School & 25 & 3.78 & 1.014 & 0.181 & NS & 3.51 & 1.512 & 0.266 & NS \\
\hline Jnanpith High School & 25 & 3.59 & 0.737 & 0.181 & NS & 3.44 & 0.844 & 0.266 & NS \\
\hline \multirow[t]{2}{*}{ Kadamtala High School } & 25 & 3.76 & 0.681 & 0.181 & $\mathrm{NS}$ & 3.49 & 1.557 & 0.266 & NS \\
\hline & & \multicolumn{4}{|c|}{ Iliac Creast } & \multicolumn{4}{|c|}{ Medial Calf } \\
\hline Age 13 & & & & & & & & & \\
\hline Sukhiapokhori HS School & 25 & 3.99 & 1.722 & 0.327 & NS & 3.48 & 0.905 & 0.214 & 0.600 \\
\hline Trunbull HS School & 25 & 4.64 & 2.341 & 0.327 & $\mathrm{NS}$ & 4.61 & 1.699 & 0.214 & 0.600 \\
\hline Jnanpith High School & 25 & 4.12 & 0.850 & 0.327 & NS & 3.26 & 0.584 & 0.214 & 0.600 \\
\hline Kadamtala High School & 25 & 4.39 & 1.229 & 0.327 & NS & 3.50 & 0.735 & 0.214 & 0.600 \\
\hline
\end{tabular}

Table-4. Analysis of variance of skinfold measurements

\begin{tabular}{|c|c|c|c|c|c|c|c|c|c|c|}
\hline \multirow[b]{2}{*}{ Source } & \multicolumn{5}{|l|}{ Biceps } & \multicolumn{5}{|l|}{ Triceps } \\
\hline & \begin{tabular}{|l} 
Sum of \\
Squares
\end{tabular} & df & $\begin{array}{l}\text { Mean } \\
\text { Square }\end{array}$ & $\mathbf{F}$ & Sig. & \begin{tabular}{|ll} 
Sum & of \\
Squares
\end{tabular} & df & \begin{tabular}{|l} 
Mean \\
Square
\end{tabular} & F & Sig. \\
\hline Altitude & .781 & 3 & .260 & .866 & .462 & 11.620 & 3 & 3.873 & 2.544 & .061 \\
\hline Error & 28.860 & 96 & .301 & & & 146.169 & 96 & 1.523 & & \\
\hline Total & 463.530 & 100 & & & & 1801.280 & 100 & & & \\
\hline \multirow[b]{2}{*}{ Source } & \multicolumn{5}{|c|}{ Sub Scapular } & \multicolumn{5}{|c|}{ Supra Spinale } \\
\hline & \begin{tabular}{|l|} 
Sum of \\
Squares
\end{tabular} & df & $\begin{array}{l}\text { Mean } \\
\text { Square }\end{array}$ & $\mathrm{F}$ & Sig. & $\begin{array}{|ll|}\text { Sum } & \text { of } \\
\text { Squares } & \\
\end{array}$ & df & $\begin{array}{l}\text { Mean } \\
\text { Square }\end{array}$ & $\mathrm{F}$ & Sig. \\
\hline Altitude & .556 & 3 & .185 & .225 & .879 & 2.046 & 3 & .682 & .387 & .763 \\
\hline Error & 79.014 & 96 & .823 & & & 169.284 & 96 & 1.763 & & \\
\hline Total & 1447.830 & 100 & & & & 1326.650 & 100 & & & \\
\hline \multirow[b]{2}{*}{ Source } & \multicolumn{5}{|c|}{ Iliac Creast } & \multicolumn{5}{|c|}{ Medial Calf } \\
\hline & $\begin{array}{l}\text { Sum of } \\
\text { Squares }\end{array}$ & $\mathrm{df}$ & $\begin{array}{l}\text { Mean } \\
\text { Square }\end{array}$ & $\mathrm{F}$ & Sig. & $\begin{array}{ll}\text { Sum } & \text { of } \\
\text { Squares }\end{array}$ & df & $\begin{array}{l}\text { Mean } \\
\text { Square }\end{array}$ & $\mathrm{F}$ & Sig. \\
\hline Altitude & 6.428 & 3 & 2.143 & .803 & .495 & 27.826 & 3 & 9.275 & 8.089 & .000 \\
\hline Error & 256.220 & 96 & 2.669 & & & 110.079 & 96 & 1.147 & & \\
\hline Total & 2098.770 & 100 & & & & 1515.800 & 100 & & & \\
\hline
\end{tabular}


Table-5. Least Significant Difference and Multiple Comparisons for skinfold measurement

\begin{tabular}{|c|c|c|c|c|c|}
\hline & & \multicolumn{2}{|l|}{ Biceps } & \multicolumn{2}{|l|}{ Triceps } \\
\hline (I) Altitude & (J) Altitude & $\begin{array}{l}\text { Mean Difference } \\
(\mathbf{I}-\mathbf{J})\end{array}$ & Sig. & $\begin{array}{l}\text { Mean } \\
\text { Difference (I- } \\
\text { J) }\end{array}$ & Sig. \\
\hline \multirow{3}{*}{$\begin{array}{l}\text { Sukhiapokhori } \\
\text { School }\end{array}$} & Trunbull HS School & -0.200 & 0.200 & -0.192 & 0.584 \\
\hline & Jnanpith High School & 0.008 & 0.959 & 0.348 & 0.321 \\
\hline & Kadamtala High School & 0.004 & 0.979 & $0.700^{*}$ & 0.048 \\
\hline \multirow[t]{2}{*}{ Trunbull HS School } & Jnanpith High School & 0.208 & 0.183 & 0.540 & 0.125 \\
\hline & Kadamtala High School & 0.204 & 0.191 & $0.892^{*}$ & 0.012 \\
\hline \multirow[t]{2}{*}{$\begin{array}{l}\text { Jnanpith } \\
\text { School }\end{array}$} & Kadamtala High School & -0.004 & 0.979 & 0.352 & 0.316 \\
\hline & & \multicolumn{2}{|l|}{ Sub Scapular } & \multicolumn{2}{|l|}{ Supra Spinale } \\
\hline \multirow{3}{*}{$\begin{array}{l}\text { Sukhiapokhori } \\
\text { School }\end{array}$} & Trunbull HS School & -0.112 & 0.663 & -0.356 & 0.346 \\
\hline & Jnanpith High School & 0.076 & 0.768 & -0.280 & 0.458 \\
\hline & Kadamtala High School & -0.088 & 0.732 & -0.336 & 0.373 \\
\hline \multirow[t]{2}{*}{ Trunbull HS School } & Jnanpith High School & 0.188 & 0.466 & 0.076 & 0.840 \\
\hline & Kadamtala High School & 0.024 & 0.926 & 0.020 & 0.958 \\
\hline \multirow[t]{2}{*}{$\begin{array}{l}\text { Jnanpith } \\
\text { School }\end{array}$} & Kadamtala High School & -0.164 & 0.524 & -0.056 & 0.882 \\
\hline & & \multicolumn{2}{|l|}{ Iliac Creast } & \multicolumn{2}{|l|}{ Medial Calf } \\
\hline \multirow{3}{*}{$\begin{array}{l}\text { Sukhiapokhori } \\
\text { School }\end{array}$} & Trunbull HS School & -0.656 & 0.159 & $-1.136^{*}$ & 0.000 \\
\hline & Jnanpith High School & -0.128 & 0.782 & 0.212 & 0.486 \\
\hline & Kadamtala High School & -0.404 & 0.384 & -0.020 & 0.947 \\
\hline \multirow[t]{2}{*}{ Trunbull HS School } & Jnanpith High School & 0.528 & 0.256 & $1.348^{*}$ & 0.000 \\
\hline & Kadamtala High School & 0.252 & 0.587 & $1.116^{*}$ & 0.000 \\
\hline $\begin{array}{l}\text { Jnanpith } \\
\text { School }\end{array}$ & Kadamtala High School & -0.276 & 0.552 & -0.232 & 0.446 \\
\hline
\end{tabular}

From the above table it was found that the mean biceps thickness of Group-I (7200 ft.), Group-II (6700 ft.), Group-III (3000 ft.) and Group-IV (430 ft.) were 2.04 mm., 2.24 mm., 2.03 $\mathrm{mm}$. and $2.03 \mathrm{~mm}$. As there was slight difference in biceps thickness among the 14 years boys of four different altitudes, analysis of variance was conducted in which "F" value found shows no significant difference. Further L.S.D was conducted to know whether the difference may occur in between the groups, which show no significant difference.

It was found from the study of Chakrabarty and Bharati (2008) that the average biceps skinfold thickness of 14 year old Shabar Tribal Adolescents of Orissa was $3.2 \mathrm{~mm}$. with S.D of 0.6 and for Bengali Boys of Nimta, West Bengal it was $4.6 \mathrm{~mm}$. with S.D of 1.7 (Mukhopadhyay et al., 2005).

In biceps skinfold difference was there but was not stastically significant. These might be due to genetic factors and same food habit provide by government in the school. 
From the above table it was found that the mean triceps thickness of Group-I (7200 ft.), Group-II (6700 ft.), Group-III (3000 ft.) and Group-IV (430 ft.) were $4.27 \mathrm{~mm}$., $4.46 \mathrm{~mm} ., 3.92$ $\mathrm{mm}$. and $3.57 \mathrm{~mm}$. Though Critical difference was not significant in tricep skinfold thickness among the boys of four different altitudes, analysis of variance was conducted in which " $F$ " value (2.544) shows no significant difference. So further L.S.D was conducted to know in which groups the difference lies and it was found that between Group-I and Group-IV and between Group-II and Group-IV the triceps thickness was significantly different from each other at 0.05 levels.

It was found from the study of Fryar et al. (2012), the average triceps skinfold thickness of 14 year old adolescents of united states was $12.9 \mathrm{~mm}$. with SEM of 0.83, for Shabar Tribal Adolescents of Orissa it was $5.6 \mathrm{~mm}$. with S.D of 1.8 (Chakrabarty and Bharati, 2008) and for Bengali Boys of Nimta, North 24 Parganas, West Bengal it was $7.3 \mathrm{~mm}$. with S.D of 2.4 (Mukhopadhyay et al., 2005).

It was found that with increase in altitude thickness increases although altitude-6700 ft. male students had thickest triceps skinfolds which may be due to genetic factors. Apart from this, thicker triceps fat saves body from low temperature may be supporting aspect.

Similarly the mean sub scapular skinfold thickness of Group-I (7200 ft.), Group-II (6700 ft.), Group-III (3000 ft.) and Group-IV (430 ft.) were $3.67 \mathrm{~mm}$., $3.78 \mathrm{~mm}$., $3.59 \mathrm{~mm}$. and $3.76 \mathrm{~mm}$. Though Critical difference was not significant in sub scapular skinfold thickness among the 13 years boys of four different altitudes, analysis of variance was conducted in which " $F$ " value (.225) shows no significant difference. So further L.S.D was conducted to know whether the difference lies in between any group or not and it was found that there was no significant difference between any group.

It was found from the study of Fryar et al. (2012), the average sub scapular skinfold thickness of 14 year old adolescents of united states was $11 \mathrm{~mm}$. with SEM of 0.68, for Shabar Tribal Adolescents of Orissa it was 7 with S.D of 1.6 (Chakrabarty and Bharati, 2008) and for Bengali Boys of Nimta, North 24 Parganas, West Bengal it was $9.3 \mathrm{~mm}$. with S.D of 3.7 (Mukhopadhyay et al., 2005).

Sub scapular skinfold thickness difference was not significant but difference may be due to genetic factors.

Similarly the mean supra spinale skinfold thickness of Group-I (7200 ft.), Group-II (6700 ft.), Group-III (3000 ft.) and Group-IV (430 ft.) were $3.16 \mathrm{~mm}$., $3.51 \mathrm{~mm}$., $3.44 \mathrm{~mm}$. and $3.49 \mathrm{~mm}$. Though Critical difference was not significant in supra spinale skinfold thickness among the boys of four different altitudes, analysis of variance was conducted in which "F" value (.387) shows no significant difference. So further L.S.D was conducted to know whether the difference lies in between any group or not and it was found that there was no significant difference between any group.

It was found from the study of Oyewale et al. (2010) that the average supra spinale skinfold thickness of 13-15 years old adolescents of Zaria, Nigeria was $0.48 \mathrm{~cm}$ with S.D of 0.15.

Supra spinale thicknesses differ but are not statistically significant. This difference may be due to genetic factors. 
From the above table it was found that the mean Iliac creast skinfold thickness of Group-I (7200 ft.), Group-II (6700 ft.), Group-III (3000 ft.) and Group-IV (430 ft.) were $3.99 \mathrm{~mm} ., 4.64$ $\mathrm{mm} ., 4.12 \mathrm{~mm}$. and $4.39 \mathrm{~mm}$. As there was slight difference in Iliac creast thickness among the 14 years boys of four different altitudes, analysis of variance was conducted in which " $F$ " value found shows no significant difference. Further L.S.D was conducted to know whether the difference may occur in between the groups, which show no significant difference.

It was found from the study of Chakrabarty and Bharati (2008) that the average Iliac creast skinfold thickness of 14 year old Shabar Tribal Adolescents of Orissa was 5.7 mm.with S.D of 1.5 and for Bengali Boys of Nimta, North 24 Parganas, West Bengal it was $9.5 \mathrm{~mm}$. with S.D of 4.3 (Mukhopadhyay et al., 2005).

Iliac creast thicknesses differ but are not statistically significant. This difference may be due to genetic factors.

Similarly the mean medial calf skinfold thickness of Group-I (7200 ft.), Group-II (6700 ft.), Group-III (3000 ft.) and Group-IV (430 ft.) were $3.48 \mathrm{~mm}$., $4.61 \mathrm{~mm}$., $3.26 \mathrm{~mm}$. and $3.50 \mathrm{~mm}$. As Critical difference was significant in medial calf skinfold thickness among the boys of four different altitudes, analysis of variance was conducted in which "F" value (8.089) shows significant difference. So further L.S.D was conducted to know where the difference lies and it was found that there was significant difference between Group-I and Group-II, between Group-II and Group-III and between Group-II and Group-IV.

It was found from the study of Mukhopadhyay et al. (2005) that the average medial calf skinfold thickness of 14 year old Bengali Boys of North 24 Parganas, W. Bengal was $8.4 \mathrm{~mm}$. with S.D of 2.2 .

Medial calf skinfolds significantly vary in age group 14. Males residing at an altitude of 6700 feet had thicker skinfolds. This may be due to genetic factors. Apart from this thicker fat layer had been accumulated by body to save itself from severe cold which occurs with increase in altitude.

Table-6. Mean and S.D of motor performance

\begin{tabular}{|c|c|c|c|c|c|c|c|c|c|}
\hline \multirow[b]{2}{*}{ Altitude } & \multicolumn{5}{|c|}{ Shuttle Run } & \multicolumn{4}{|c|}{50 mt.dash } \\
\hline & $\mathbf{N}$ & Mean & SD & $\begin{array}{l}\text { SEm } \\
( \pm)\end{array}$ & $\begin{array}{l}\mathrm{CD} \\
(\mathrm{P}=0.05)\end{array}$ & Mean & SD & $\begin{array}{l}\text { SEm } \\
( \pm)\end{array}$ & $\begin{array}{l}\mathrm{CD} \\
(\mathrm{P}=0.05)\end{array}$ \\
\hline \multicolumn{10}{|l|}{ Age 13} \\
\hline Sukhiapokhori HS School & 25 & 11.93 & 0.817 & 0.118 & 0.331 & 8.60 & 0.466 & 0.088 & $\mathrm{NS}$ \\
\hline Trunbull HS School & 25 & 11.18 & 0.470 & 0.118 & 0.331 & 8.66 & 0.402 & 0.088 & $\mathrm{NS}$ \\
\hline Jnanpith High School & 25 & 10.62 & 0.474 & 0.118 & 0.331 & 8.45 & 0.333 & 0.088 & $\mathrm{NS}$ \\
\hline \multirow[t]{2}{*}{ Kadamtala High School } & 25 & 11.67 & 0.521 & 0.118 & 0.331 & 8.77 & 0.529 & 0.088 & $\mathrm{NS}$ \\
\hline & \multicolumn{5}{|c|}{\begin{tabular}{|l|} 
Standing Broad Jump \\
\end{tabular}} & \multicolumn{4}{|c|}{ Sit Ups } \\
\hline Sukhiapokhori HS School & 25 & 1.70 & 0.179 & 0.032 & $\mathrm{NS}$ & 15.00 & 3.617 & 0.581 & 1.629 \\
\hline Trunbull HS School & 25 & 1.76 & 0.187 & 0.032 & $\mathrm{NS}$ & 17.48 & 2.330 & 0.581 & 1.629 \\
\hline Jnanpith High School & 25 & 1.72 & 0.128 & 0.032 & $\mathrm{NS}$ & 15.48 & 2.163 & 0.581 & 1.629 \\
\hline Kadamtala High School & 25 & 1.72 & 0.129 & 0.032 & $\mathrm{NS}$ & 20.76 & 3.257 & 0.581 & 1.629 \\
\hline
\end{tabular}


Table-7. Analysis of variance of motor performance

\begin{tabular}{|c|c|c|c|c|c|c|c|c|c|c|}
\hline \multirow[b]{2}{*}{ Source } & \multicolumn{5}{|l|}{ Shuttle Run } & \multicolumn{5}{|l|}{$50 \mathrm{mt}$. dash } \\
\hline & $\begin{array}{ll}\text { Sum of } \\
\text { Squares }\end{array}$ & df & $\begin{array}{l}\text { Mean } \\
\text { Square }\end{array}$ & $\mathbf{F}$ & Sig. & $\begin{array}{ll}\text { Sum of } \\
\text { Squares }\end{array}$ & df & $\begin{array}{l}\text { Mean } \\
\text { Square }\end{array}$ & $\mathbf{F}$ & Sig. \\
\hline Altitude & 25.085 & 3 & 8.362 & 24.169 & .000 & 1.403 & 3 & .468 & 2.431 & .070 \\
\hline Error & 33.214 & 96 & .346 & & & 18.464 & 96 & .192 & & \\
\hline \multirow[t]{2}{*}{ Total } & 12936.46 & 100 & & & & 7448.583 & 100 & & & \\
\hline & \multicolumn{5}{|c|}{ Standing Broad Jump } & \multicolumn{5}{|l|}{ Sit Ups } \\
\hline Altitude & .049 & 3 & .016 & .647 & .587 & 513.720 & 3 & 171.24 & 20.269 & .000 \\
\hline Error & 2.401 & 96 & .025 & & & 811.040 & 96 & 8.448 & & \\
\hline Total & 300.289 & 100 & & & & 30840.000 & 100 & & & \\
\hline
\end{tabular}

Table-8. LSD, Multiple Comparisons for motor performance

\begin{tabular}{|c|c|c|c|c|c|}
\hline & & \multicolumn{2}{|l|}{ Shuttle Run } & \multicolumn{2}{|l|}{$50 \mathrm{mt}$. dash } \\
\hline (I) Altitude & (J) Altitude & $\begin{array}{l}\text { Mean Difference } \\
(\mathrm{I}-\mathrm{J})\end{array}$ & Sig. & $\begin{array}{l}\text { Mean Difference } \\
(\mathrm{I}-\mathrm{J})\end{array}$ & Sig. \\
\hline \multirow{3}{*}{$\begin{array}{l}\text { Sukhiapokhori } \\
\text { School }\end{array}$} & Trunbull HS School & $0.7492^{*}$ & .000 & -0.0584 & 0.639 \\
\hline & Jnanpith High School & $1.3100^{*}$ & .000 & 0.1540 & 0.217 \\
\hline & Kadamtala High School & 0.2552 & .128 & -0.1748 & 0.162 \\
\hline \multirow[t]{2}{*}{ Trunbull HS School } & Jnanpith High School & $0.5608^{*}$ & .001 & 0.2124 & 0.090 \\
\hline & Kadamtala High School & $-.4940^{*}$ & .004 & -0.1164 & 0.350 \\
\hline \multirow[t]{2}{*}{ Jnanpith High School } & Kadamtala High School & $-1.0548^{*}$ & .000 & $-0.3288^{*}$ & 0.009 \\
\hline & & \multicolumn{2}{|c|}{ Standing Broad Jump } & \multicolumn{2}{|l|}{ Sit Ups } \\
\hline \multirow{3}{*}{$\begin{array}{l}\text { Sukhiapokhori } \\
\text { School }\end{array}$} & Trunbull HS School & -0.0588 & 0.192 & $-2.4800^{*}$ & 0.003 \\
\hline & Jnanpith High School & -0.0168 & 0.708 & -0.4800 & 0.561 \\
\hline & Kadamtala High School & -0.0132 & 0.769 & $-5.7600^{*}$ & 0.000 \\
\hline \multirow[t]{2}{*}{ Trunbull HS School } & Jnanpith High School & 0.0420 & 0.350 & $2.0000^{*}$ & 0.017 \\
\hline & Kadamtala High School & 0.0456 & 0.311 & $-3.2800^{*}$ & 0.000 \\
\hline Jnanpith High School & Kadamtala High School & 0.0036 & 0.936 & $-5.2800^{*}$ & 0.000 \\
\hline
\end{tabular}

From the above table it was found that in the age group of 14, the mean time of shuttle run of Group-I (7200 ft.), Group-II (6700 ft.), Group-III (3000 ft.) and Group-IV (430 ft.) were 11.93 seconds, 11.18 seconds, 10.62 seconds and 11.67 seconds. As there was critical difference in shuttle run among the 14 years boys of four different altitudes, analysis of variance was conducted in which "F" value (24.169) found shows significant difference so, further L.S.D was conducted to know where the difference lies in between the groups and it was found that there was significant difference between Group-I and Group-II, between Group-I and Group-III, between Group-II and Group-III, between Group-II and Group-IV and between Group-III and Group-IV.

It was found from the study of P.K. Paul (2013), the average shuttle run speed (m/sec) of 14 year old male students of 24 Pgs (N), West Bengal was $11.20 \mathrm{sec}$ with S.D of .46 and worldwide average shuttle run speed was 11.517 with S.D of 1.323 (Old et al., 2006). Analysing the result of 
shuttle run it may be concluded that the present study has close proximity to Paul (2013) and Old et al. (2006).

There were significant differences in shuttle run among four different altitudes. Male students residing at an altitude of 3000 feet showed best performance which may be due to genetic factor. Among four altitudes, these altitude male were more laborious as they depend on agriculture for their livelihood resulting in well developed calf muscle.

In $50 \mathrm{mt}$. dash there was significant difference in age group 15 and 16 only. Students residing at highest altitude (7200 ft.) showed better performance which may be due to genetic factor. Apart from these physiological factors like high haemoglobin content, increase in blood etc may be supporting factors.

Similarly the mean value of 50 meter run of Group-I (7200 ft.), Group-II (6700 ft.), Group-III (3000 ft.) and Group-IV (430 ft.) were 8.60 seconds, 8.66 seconds, 8.45 seconds and 8.77 seconds. Though there was no critical difference in 50 meter run among the 14 year boys of four different altitudes, analysis of variance was conducted in which "F" value (2.431) found shows no significant difference so further L.S.D was conducted to know whether the difference occurs in between the groups and it was found that there was significant difference between Group-III and Group-IV.

It was found from the study of Paul (2013), the average $50 \mathrm{mt}$. run speed (m/sec) of 14 year old male students of 24 Pgs (N), West Bengal was $8.36 \mathrm{sec}$ with S.D of .72.

In $50 \mathrm{mt}$. dash there was no significant difference but still Students residing at altitude III (3000 ft.) showed better performance which may be due to genetic factor. Apart from these physiological factors like high haemoglobin content, increase in blood etc may be supporting factors.

From the above table it was found that in the age group of 14, the mean lengthwise coverage of standing broad jump of Group-I (7200 ft.), Group-II (6700 ft.), Group-III (3000 ft.) and GroupIV (430 ft.) were 1.70 meter, 1.76 meter, 1.72 meter and 1.72 meter. As there was no critical difference in standing broad jump among boys of four different altitudes, analysis of variance was conducted in which "F" value (.647) found shows no significant difference so, further L.S.D was conducted to know whether the difference lies in between the groups and it was found that there was no significant difference between any groups.

It was found from the study of Paul (2013), the average standing broad jump of 14 year old male students of 24 Pgs (N), West Bengal was $171.37 \mathrm{~cm}$ with S.D of 15.92. and for Macedonian school children it was $180.5 \mathrm{~cm}$ with S.D of 28.07 (Gontarev et al., 2014). Analysing the result of standing broad jump it may be concluded that the present study has close proximity to Paul (2013).

In standing broad jump, there were no significant difference but Altitude-6700 ft. male students had greater explosive strength which may be due to genetic factors. Apart from this it may be due to well developed calf muscle shaped while walking up and down the hilly roads.

Similarly the mean value of sit ups of Group-I (7200 ft.), Group-II (6700 ft.), Group-III (3000 $\mathrm{ft}$.) and Group-IV (430 ft.) were 12.00, 17.48, 15.48 and 20.76. As there was critical difference in 
sit ups among the boys of four different altitudes, analysis of variance was conducted in which "F" value (20.269) found shows highly significant difference so further L.S.D was conducted to know where the difference lies in between the groups and it was found that there was significant difference between Group-I and Group-II, between Group-I and Group-IV and between Group-II and Group-III, between Group-II and Group-IV and between Group-III and Group-IV.

Subjects residing at lowest altitude (430 ft.) showed better performance which may be due to genetic factors. Apart from this it may be due to shorter upper body as upper body part decrease with decrease in altitude.

Table-9. Correlation between body composition and motor performance

\begin{tabular}{|c|c|c|c|c|c|}
\hline & & \multicolumn{4}{|l|}{ Age 14} \\
\hline & & MT 50 & SBJ & S UPS & S Run \\
\hline \multirow[t]{2}{*}{ Biceps } & "r" value & 0.324 & $-.470^{*}$ & -0.213 & 0.199 \\
\hline & Probability & 0.115 & 0.018 & 0.307 & 0.340 \\
\hline \multirow[t]{2}{*}{ Triceps } & “r” value & 0.098 & $-.542^{* *}$ & -0.055 & 0.236 \\
\hline & Probability & 0.640 & 0.005 & 0.794 & 0.257 \\
\hline \multirow[t]{2}{*}{ SScapular } & "r" value & 0.107 & -0.158 & -0.027 & 0.070 \\
\hline & Probability & 0.610 & 0.451 & 0.899 & 0.738 \\
\hline \multirow[t]{2}{*}{ SSpinale } & “r” value & 0.241 & -0.096 & -0.121 & 0.063 \\
\hline & Probability & 0.246 & 0.648 & 0.565 & 0.764 \\
\hline \multirow[t]{2}{*}{ ICreast } & "r" value & 0.068 & -0.190 & 0.035 & 0.041 \\
\hline & Probability & 0.747 & 0.363 & 0.869 & 0.846 \\
\hline \multirow[t]{2}{*}{ MCalf } & "r" value & 0.121 & $-.410^{*}$ & -0.004 & 0.026 \\
\hline & Probability & 0.565 & 0.042 & 0.986 & 0.900 \\
\hline
\end{tabular}

50 meter dash has no significant correlation with any skinfold thickness. In between standing broad jump and body composition, there was significant correlation with biceps, triceps and medial calf.

In case of correlation between sit ups and body composition it was found that there was no statistically significant correlation. In case of correlation between shuttle run and body composition it was found there was no statistically significant correlation with skinfolds.

\section{CONCLUSION}

From above findings following conclusions can be drawn;

1. There is a significant difference in medial calf skinfold thickness. Group-II (6700 ft.) boys have thickest medial calf than remaining groups. Significant difference was found between Group-I and Group-II, between Group-II and Group-III and between Group-II and Group-IV.

2. In agility Group-III (3000 ft.) boys were superior than other groups.

3. In 50 meter dash Group-III (3000 ft.) boys shows superior performance and statistically significant difference was observed between Group-III and Group-IV. 
4. In explosive strength Group-II (6700 ft.) boys shows superior performance than other groups but were not statistically significant.

5. In strength endurance Group-IV (430 ft.) boys were superior to other three groups.

6. There was significant correlation of S.B. jump with biceps, triceps and medial calf.

Funding: This study received no specific financial support.

Competing Interests: The authors declare that they have no competing interests.

Contributors/Acknowledgement: All authors contributed equally to the conception and design of the study.

\section{REFERENCES}

Chakrabarty, S. and P. Bharati, 2008. Physical growth and nutritional status of the shabar tribal adolescents of Orissa, India: A cross-sectional study. Mal J Nutr, 14(1): 101-112.

Fryar, C., Q. Gu and C. Ogden, 2012. Anthropometric reference data for children and adults: United States, 2007-2010. National center for health statistics. Vital Health Stat, 11(252).

Gontarev, S., V. Zivkovic, L.A. Velickovska and M.M. Naumovski, 2014. First normative reference of standing long jump indicates gender difference in lower muscular strength of Macedonian school children. Health, 6(1): 99-106.

Mukhopadhyay, A., M. Bhadra and B. Kaushik, 2005. Regional adiposity, body composition and central body fat distribution of 10-16 years old Bengalee boys of Nimta, North 24 parganas, West Bengal, India. Coll. Antropol, 29(2): 487-492.

Old, T., G. Tomkinson, L. Leger and G. Cazorla, 2006. Worldwide variation in the performance of children and adolescents: An analysis of 109 studies of the 20-m shuttle run test in 37 countries. Journal of Sports Sciences, 24(10): 1025-1038.

Oyewale, A.A., S.A. Ojo, S.S. Adebisi and S.B. Danborno, 2010. The study of anthropometric variables on growth and development of school children in Zaria, Nigeria. Asian Journal of Medical Sciences, 2(4): 185-189.

Paul, P.K., 2013. Age related changes on growth and motor performance of 13 \& 14 years boys. International Educational E-Journal, 2(3): 99-106.

\section{BIBLIOGRAPHY}

Gupta, R. and A. Basu, 2005. Altitude and growth among the sherpas of the Eastern Himalayas. American Journal of Human Biology, 3(1): 1-9.

Johnson and Nelson, 1935. Practical measurements for evaluation in physical education. Burges Publishers.

Michael, M.J., O. Tim, S. Arthur and J.E. Carter, 2001. International standards for anthropometric assessment. Cataloguing-in-Publishers.

Views and opinions expressed in this article are the views and opinions of the author(s), Journal of Sports Research shall not be responsible or answerable for any loss, damage or liability etc. caused in relation to/arising out of the use of the content. 